\title{
FORMULATION DEVELOPMENT AND EVALUATION OF LIPOSOME FOR TOPICAL DELIVERY
}

\author{
Rakesh Tiwari*, Mithun Bhowmick, Jagdish Rathi \\ NRI Institute of Pharmaceutical Sciences, Bhopal (M.P)
}

Article Info: Received 15 September 2018; Accepted 02 January. 2019

Cite this article as: Tiwari, R., Bhowmick, M., \& Rathi, J. (2019). Formulation development and evaluation of liposome for topical delivery. Journal of Biomedical and Pharmaceutical Research, 8(1):01-12 https://doi.org/https://doi.org/10.32553/jbpr.v7i6.564

DOI: https://doi.org/10.32553/jbpr.v7i6.564

Address for Correspondence: Rakesh Tiwari, NRI Institute of Pharmaceutical Sciences, Bhopal (M.P)

Conflict of interest statement: No conflict of interest

\section{ABSTRACT:}

and side effects. So the objective of the present research work is to reduce the side effects, Topical administration of drug is better for local action and the efficiency of the topically administered drug is increased with vesicles like Liposomes. Liposomes were prepared by rotator evaporation method and optimized on the basis of average vesicle size, \% drug entrapment and polydispersity index. The optimized formulation was further encorpoated with gel base (carbapol gel) and characterized for their viscosity, extrudability, spreadability and drug release study. The NSAIDs is mainly used for the treatment of rheumatoid arthritis and osteoarthritis. Sulfasalazine is non steroidal anti inflammatory drug with analgesic, antipyretic and anti inflammatory activity and it is commonly used in the treatment of acute mild to moderate pain, as well as inflammation of the joints caused by certain type of rheumatoid arthritis. The sulfasalazine drug has less bioavailability(10-30\%), more dose frequency dose frequency, increase the bioavailability and therapheutic efficacy. So sulfasalazine is chosen for development of liposome preparation.

Keywords: Liposomes, rheumatoid arthritis, sulfasalazine

\section{INTRODUCTION}

Sulfasalazine is in the disease-modifying antirheumatic drugs (DMARDs) family of medications. Sulfasalazine drug is having half life of 5 to $7 \mathrm{~h}$ and used for the treatment of rheumatoid arthritis. The oral use of Sulfasalazine is not much recommended as it requires frequent administration. The entrapment of drug in a vesicle has shown improved delivery of drug at the targeted site and has also reduced the side effects thus, has shown better patient compliance. Numerous dosage forms are used in the topical treatment of superficial fungal infections, including creams, liquids, gels, ointments, lacquers and others. The treatment of athlete's foot and ringworm can easily be accomplished with creams, liquids, gels and ointments. The need for sustained delivery of sulfasalazine is further justified due to the requirement of maintaining un-fluctuating plasma concentrations for the effective management of Antiinflammatory drug. In such conditions transdermal drug delivery remains the most favored mode of administration where the hepatic metabolism of drug can be bypassed. But, stratum corneum forms the most formidable barrier for the penetration of drug through skin. To overcome the stratum corneum barrier, the 
use of lipid vesicles like liposomes in delivery systems has attracted increasing attention in recent years. Among these, liposome is reported to have the potential of overcoming the stratum corneum barrier and enhance the permeability of drug through the skin. ${ }^{1-4}$

\section{MATERIALS AND METHODS}

\section{Materials}

Sulfasalazine was obtained as a gift sample from Wallace Pharmaceutical Pvt. Ltd., Goa. Lecithin (PC; Phospholipon 90H) was a generous gift from Nattermann phospholipids $\mathrm{GmbH}$, Germany. Cholesterol (CHOL) was purchased from Qualigens Fine Chemicals, Mumbai, India. All other chemicals used were of HPLC or analytical grade.

\section{Methods}

\section{Preformulation ${ }^{5-6}$}

\section{Characterization of Drug:}

\section{Physiochemical Properties of Sulfasalazine}

\section{A) Organoleptic evaluation}

It was done by evaluation of sensory characters like taste, appearance, odor etc.

\section{B) Solubility (at room temperature)}

Solubility can be defined as the property of a solute (solid, liquid, or gaseous chemical substance) to dissolve in a solid, liquid, or gaseous solvent to form a identical solution of the solute in the solvent. The solubility of a substance is the quantity of that solute that will dissolve in a given quantity of solvent. It is a important parameter for dosage form designing.

\section{Procedure:}

Approximately 1 gram of drug was weighed accurately and transferred to 5 different $10 \mathrm{ml}$. volumetric flasks. Different solvents (water, 0.1 $\mathrm{N} \mathrm{HCl}, 0.1 \mathrm{~N} \mathrm{NaOH}$, Ethanol, Methanol, $7.2 \mathrm{pH}$ phosphate buffer and Chloroform) were added to the flask respectively and the solubility was observed.
Table 1: I.P. Ranges for Solubility

\begin{tabular}{|l|l|}
\hline Descriptive term & $\begin{array}{l}\text { Parts of solvent } \\
\text { required for Parts } \\
\text { of soluble }\end{array}$ \\
\hline Very soluble & Less than 1 \\
\hline Freely soluble & From 1to 10 \\
\hline Soluble & From 10 to 30 \\
\hline Sparingly soluble & From 30 to 100 \\
\hline slightly soluble & From 100 to 1000 \\
\hline Very slightly soluble & From 1000 to 10000 \\
\hline Practically insoluble & 10000 or more \\
\hline
\end{tabular}

\section{C) Identification Test}

\section{FTIR Spectroscopy:}

Infra- red spectrum is an important record which gives sufficient information about the structure of a compound. This technique provides a spectrum containing a large number of absorption band from which a wealth of information can be derived about the structure of an organic compound.

\section{Procedure}

\section{IR study carried out by $\mathrm{KBr}$ press pellet Technique}

The concentration of the sample in $\mathrm{KBr}$ should be in the range of $0.2 \%$ to $1 \%$. The pellet is much thicker than a liquid film, hence a lower concentration in the sample is required (Beer's Law). For the die set that you will be using, about $80 \mathrm{mg}$ of the mixture are needed. Too high of a concentration causes usually difficulties to obtain clear pellets. This pellet keeps into the sample cell and scanned between $4000-400$ c.m ${ }^{-1}$ and spectra of IR collected.

\section{D) Loss on drying}

Loss on drying was directly measured by IR moisture balance. Firstly the instrument was calibrated by rotating knob. Approximately 5 gram powdered drug was weighed accurately. The temperature was fixed at $100^{\circ} \mathrm{C}$ to $105^{\circ} \mathrm{C}$ for 5 minutes and constant readings was taken 
by setting the knob and \% moisture was determined.

\section{E) Determination of $\mathrm{pH}(1 \% \mathrm{w} / \mathrm{v}$ solution in water)}

$\mathrm{pH}$ was determined by digital $\mathrm{pH}$ meter. In this method approximately 1 gram of the drug was taken and dissolved in $100 \mathrm{ml}$. of distilled water with sonication and filtered, $\mathrm{pH}$ of the filtrate was checked with standard glass electrode.

\section{F) Melting point}

It is one of the parameters for the purity of drugs. In case of pure chemicals, melting points are very sharp and constant. Since the drugs contain the mixed chemicals, they are described with certain range of melting point.

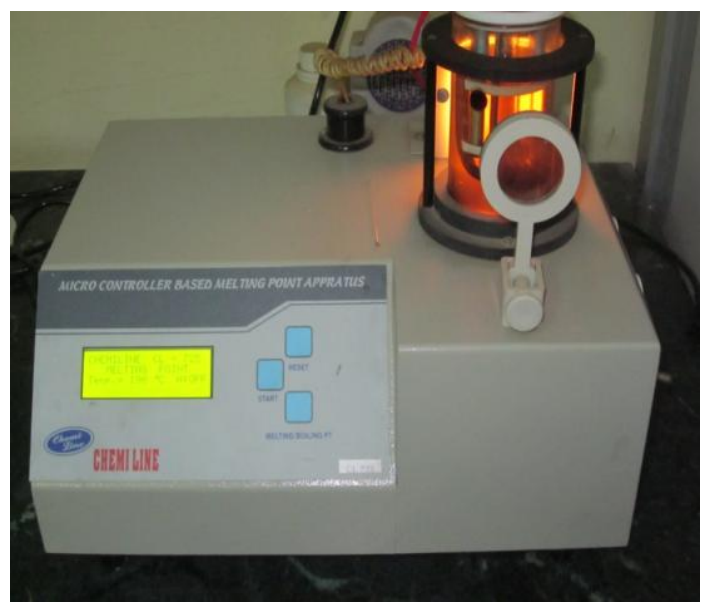

Figure 1: Photograph taken during Melting Point Determination

Procedure for determine melting point:

A small quantity of drug was placed into a capillary tube, and then it was placed in the melting point determining apparatus containing liquid paraffin. The temperature of the liquid paraffin was gradual increased automatically and reading was taken at which sample started to melt till all sample gets melted.

\section{M) Determination of $\boldsymbol{\lambda}$ max of Sulfasalazine}

The absorption maxima of Sulfasalazine were determined by running the spectrum of drug solution in double beam ultraviolet spectrophotometer.

\section{Calibration curve of Sulfasalazine}

Preparation of Standard Stock Solution

$10 \mathrm{mg}$ of Sulfasalazine was weighed accurately and transferred to $10 \mathrm{ml}$ volumetric flask, and the volume was adjusted to the mark with the $7.2 \mathrm{pH}$ phosphate buffer to give a stock solution of $1000 \mathrm{ppm}$ or $\mu \mathrm{g} / \mathrm{ml}$.

\section{Preparation of Working Standard Solution:-}

From stock solutions of Sulfasalazine $1 \mathrm{ml}$ was taken and diluted up to $10 \mathrm{ml}$ separate volumetric flask give $100 \mathrm{ppm}$ or $\mu \mathrm{g} / \mathrm{ml}$ standard solution. From this solution $0.5,1.0$, 1.5, 2.0 and $2.5 \mathrm{ml}$ solutions were transferred to $10 \mathrm{ml}$ volumetric flasks and make up the volume up to $10 \mathrm{ml}$ with mobile phase, gives standard drug solution of $5,10,15,20,25$ $\mu \mathrm{g} / \mathrm{ml}$ concentrations of Sulfasalazine.

\section{Preparation of Sulfasalazine loaded liposomes}

Liposomes were prepared by rotator evaporation method given by Touitou et al., 2000 with slight modification in which drug was dissolved in methanol to give a concentration of $1.0 \% \mathrm{w} / \mathrm{v}$ of drug solution. The accurately weighed amounts $(10 \% \mathrm{w} / \mathrm{v})$ of phospholipids and surfactant (7:3 ratio) were taken in a clean, dry, round-bottom flask and this lipid mixture was dissolved in minimum quantity of methanol and chloroform mixture in ratio of 2:1. The round bottom flask was rotated at 45을 angle using rotator evaporator at $40^{\circ} \mathrm{C}$ in order to make uniform lipid layer. The organic solvent was removed by rotary evaporation under reduced pressure at the same temperature $\left(40^{\circ} \mathrm{C}\right)$. Final traces of solvents were removed under vacuum overnight. The prepared lipid film in the inner wall of round bottom was hydrated with $10 \%$ $w / v$ of drug solution in water followed by rotating the flask containing mixture of drug by rotation at speed of $60 \mathrm{rev} / \mathrm{min}$ for $1 \mathrm{hr}$. After complete hydration of film, the prepared formulation of liposomes was subjected to 
Rakesh Tiwari et al., Journal of Biomedical and Pharmaceutical Research

sonication at $4^{\circ} \mathrm{C}$ in 3 cycles of 10 minutes with $5 \mathrm{sec}$ rest between the cycles. The prepared formulation was stored at $4^{\circ} \mathrm{C}$ in closed container till further use for analysis. ${ }^{7-8}$

OPTIMIZATION OF LIPOSOMES ${ }^{7-8}$

Optimization of lipid: surfactant ratio
In the liposomal formulation, the amount of soya PC was optimized by taking their different amount such as 50,100, 150 and 200mg and all other parameters were kept remain constant. The prepared formulations were optimized on the basis of average particle size and entrapment efficiency

Table 2: Optimization of Soya PC concentration

\begin{tabular}{|l|l|l|l|l|l|}
\hline $\begin{array}{l}\text { Formulation } \\
\text { code }\end{array}$ & $\begin{array}{l}\text { Soya PC } \\
(\mathbf{m g})\end{array}$ & $\begin{array}{l}\text { Cholesterol } \\
\mathbf{( m g )}\end{array}$ & $\begin{array}{l}\text { Drug } \\
\mathbf{( m g})\end{array}$ & $\begin{array}{l}\text { Average vesicles } \\
\text { size }(\mathbf{n m})\end{array}$ & $\begin{array}{l}\text { \% entrapment } \\
\text { efficiency }\end{array}$ \\
\hline F-1 & 50 & 20 & 10 & $356.02 \pm 4.23$ & $76.5 \pm 4.78$ \\
\hline F-2 & 100 & 20 & 10 & $251.05 \pm 3.12$ & $72.03 \pm 3.39$ \\
\hline F-3 & 150 & 20 & 10 & $230.87 \pm 1.90$ & $41.48 \pm 3.23$ \\
\hline F-4 & 200 & 20 & 10 & $287.43 \pm 1.90$ & $28.73 \pm 2.14$ \\
\hline
\end{tabular}

* Average of three determination

\section{Optimization of drug concentration:}

Drug concentration was optimized by taking different concentration of drug and prepared their formulation and all other parameter such as Soya PC, cholesterol, sonication time kept remain constant. The formulation optimized on the basis of entrapment efficiency and average vesicle size.

Table 3: Optimization of cholesterol and drug concentration

\begin{tabular}{|c|c|c|c|c|c|}
\hline F. code & $\begin{array}{c}\text { Soya } \\
\text { phosphatidylcholine }\end{array}$ & $\begin{array}{c}\text { Cholesterol } \\
\text { (mg) }\end{array}$ & $\begin{array}{c}\text { Drug } \\
\text { (mg) }\end{array}$ & $\begin{array}{c}\text { Average } \\
\text { particle size } \\
(\mathbf{n m})\end{array}$ & $\begin{array}{c}\text { \% Entrapment } \\
\text { efficiency }\end{array}$ \\
\hline F-5 & 100 & 20 & 10 & $251.02 \pm 1.09$ & $72.03 \pm 2.39$ \\
\hline F-6 & 100 & 30 & 15 & $262.25 \pm 3.37$ & $76.03 \pm 2.49$ \\
\hline F-7 & 100 & 40 & 20 & $230.87 \pm 2.29$ & $76.48 \pm 3.23$ \\
\hline
\end{tabular}

* Average of three determination

\section{Optimization of sonication time}

Sonication time was optimized by sonicating the formulation for different time i.e 30, 60 and $90 \mathrm{sec}$ at $4^{0} \mathrm{C}$ in 3 cycles of 10 minutes with $5 \mathrm{sec}$ rest between the cycles. The optimization was done on the basis of average particle size and \% Entrapment efficiency. 
Rakesh Tiwari et al., Journal of Biomedical and Pharmaceutical Research

Table 4: Optimization of sonication time

\begin{tabular}{|c|c|c|c|c|c|}
\hline $\begin{array}{c}\text { Formulation } \\
\text { code }\end{array}$ & $\begin{array}{c}\text { Soya PC: } \\
\text { Cholesterol } \\
\text { (mg) }\end{array}$ & $\begin{array}{c}\text { Drug } \\
\text { (mg) }\end{array}$ & $\begin{array}{c}\text { Sonication } \\
\text { time } \\
\text { (Sec) }\end{array}$ & $\begin{array}{c}\text { Average } \\
\text { particle size } \\
\text { (nm) }\end{array}$ & $\begin{array}{c}\text { \% Entrapment } \\
\text { efficiency }\end{array}$ \\
\hline F-8 & $100: 40$ & 20 & 30 & $218.42 \pm 6.09$ & $72.03 \pm 2.39$ \\
\hline F-9 & $150: 40$ & 20 & 60 & $178.37 \pm 5.07$ & $71.03 \pm 2.49$ \\
\hline F-10 & $150: 40$ & 20 & 90 & $145.29 \pm 7.80$ & $45.48 \pm 3.23$ \\
\hline
\end{tabular}

* Average of three determination

Table 5: Optimized formulation liposomes

\begin{tabular}{|l|l|}
\hline \multicolumn{2}{|l|}{ Formulation code F-9 } \\
\hline Phospholipid: Surfactant (mg) & $100: 40$ \\
\hline Drug (mg) & 20 \\
\hline Sonication time (sec) & 60 \\
\hline
\end{tabular}

\section{CHARACTERIZATION OF LIPOSOMES ${ }^{\text {9-12 }}$}

\section{Surface charge and vesicle size}

The vesicles size and surface charge were determined by Dynamic Light Scattering method (DLS) (Malvern Zetamaster, ZEM 5002, Malvern, UK). Zeta potential measurement of the liposomes was based on the zeta potential that was calculated according to HelmholtzSmoluchowsky from their electrophoretic mobility. For measurement of zeta potential, a zetasizer was used with field strength of 20 $\mathrm{V} / \mathrm{cm}$ on a large bore measures cell. Samples were diluted with $0.9 \% \mathrm{NaCl}$ adjusted to a conductivity of $50 \mathrm{IS} / \mathrm{cm}$.

\section{Entrapment efficiency}

Entrapment efficiency was determined by measuring the concentration of unentrapped free drug in aqueous medium. About $1 \mathrm{ml}$ of the drug loaded liposomes dispersion was placed in the eppendorf tubes and centrifuged at $10,000 \mathrm{rpm}$ for $30 \mathrm{~min}$. The liposomes along with encapsulated drug were separated at the bottom of the tubes. Plain liposomes without sulfasalazine was used as blank sample and centrifuged in the same manner. In order to measure the free drug concentration, the UV absorbance of the supernatant was determined at $350.5 \mathrm{~nm}$. The results shown in table 8.3.

$$
\% \text { Entrapment Efficiency }=\frac{\text { Therotical drug content }- \text { Practical drug content }}{\text { Therotical drug content }} \times 100
$$




\section{Preparation Of Gel Base ${ }^{13-14}$}

Carbopol 934 (1\%w/v) was accurately weighed and dispersed into double distilled water $(80 \mathrm{ml})$ in a beaker. This solution was stirred continuously at $800 \mathrm{rpm}$ for 1 hour and then $10 \mathrm{ml}$ of propylene glycol was added to this solution. The obtained slightly acidic solution was neutralized by drop wise addition of 0.05 $\mathrm{N}$ sodium hydroxide solutions, and again mixing was continued until gel becomes transparent. Volume of gel was adjusted to $100 \mathrm{ml}$ and then sonicated for $10 \mathrm{~min}$ on bath sonicator to remove air bubbles. Final $\mathrm{pH}$ of the gel base was adjusted to 6.5. Gel was also prepared with plain drug by adding $10 \mathrm{mg}$ of drug and dispersed properly by following same procedure given above. The same procedure was used to formulate noisome containing gel in which previously prepared liposomal cake was added in place of plain drug. liposomes preparation corresponding to $1 \% \mathrm{w} / \mathrm{w}$ (10mg of drug in $100 \mathrm{mg}$ of gel) of drug was incorporated into the gel base to get the desired concentration of drug in gel base.

\section{Characterization of Liposomes Containing Gel 13-15}

\section{Measurement of viscosity}

Viscosity measurements of prepared topical liposome based gel were measured by Brookfield viscometer using spindle no. 63 with the optimum speed of 10rpm; viscosity was found to be $3776 \mathrm{cps}$.

\section{pH measurements}

$\mathrm{pH}$ of selected optimized formulations was determined with the help of digital $\mathrm{pH}$ meter. Before each measurement of $\mathrm{pH}, \mathrm{pH}$ meter should be calibrated with the help of buffer solution of $\mathrm{pH} 4, \mathrm{pH} 7$ and $\mathrm{pH}$ 9. After calibration, the electrode was dipped into the vesicles as long as covered by the vesicles. Then $\mathrm{pH}$ of selected formulation was measured and readings shown on display were noted.

\section{\% Assay}

The gel sample (100mg) was withdrawn and drug (sulfasalazine) content was determined using UV spectrophotometer at $350.5 \mathrm{~nm}$. In case of liposomal gel, it was shaken with sufficient quantity of methanol to extract the drug and then analyzed by using UV spectrophotometer at $221.40 \mathrm{~nm}$.

\section{Extrudability study}

Extrudability was based upon the quantity of the gel extruded from collapsible tube on application of certain load. More the quantity of gel extruded shows better extrudability. It was determine by applying the weight on gel filled collapsible tube and recorded the weight on which gel was extruded from tube. Extrudability of gel required 170 grams of weight to extrude a $0.6 \mathrm{~cm}$ ribbon of gel in 6 seconds.

\section{Spreadibility}

Spreadibility of formulation is necessary to provide sufficient dose available to absorb from skin to get good therapeutic response. It was determined by method reported by Multimer et al., 1956. An apparatus in which a slide fixed on wooded block and upper slide has movable and one end of movable slide tied with weight pan.To determine spreadibility, placing 2-5 g of gel between two slide and gradually weight was increased by adding it on the weight pan and time required by the top plate to cover a distance of $10 \mathrm{~cm}$ upon adding $80 \mathrm{~g}$ of weight was noted. Good spreadibility show lesser time to spread.

$$
\text { Spreadibility }(\text { g.cm } / \mathrm{sec})=\frac{\text { Weight tide to Upper Slide } \times \text { Lenth moved on the glass slide }}{\text { Time takento slide }}
$$




\section{In Vitro drug diffusion study}

He In-vitro diffusion study is carried by using Franz Diffusion Cell. Egg membrane is taken as semi permeable membrane for diffusion. The Franz diffusion cell has receptor compartment with an effective volume approximately $60 \mathrm{~mL}$ and effective surface area of permeation 3.14sq.cms. The egg membrane is mounted between the donor and the receptor compartment. A two $\mathrm{cm}^{2}$ size patch taken and weighed then placed on one side of membrane facing donor compartment. The receptor medium is phosphate buffer $\mathrm{pH}$ 7.4. The receptor compartment is surrounded by water jacket so as to maintain the temperature at 32 $\pm 0.5^{\circ} \mathrm{C}$. Heat is provided using a thermostatic hot plate with a magnetic stirrer. The receptor fluid is stirred by Teflon coated magnetic bead which is placed in the diffusion cell.

During each sampling interval, samples are withdrawn and replaced by equal volumes of fresh receptor fluid on each sampling. The samples withdrawn are analyzed spectrophotometrically at wavelength of 350.5nm. (Table 8.3)

\section{Stability Studies}

Stability study was carried out for drug loaded liposomes at two different temperatures i.e. refrigeration temperature $\left(4.0 \pm 0.2^{\circ} \mathrm{C}\right)$ and at room temperature $\left(25-28 \pm 2^{\circ} \mathrm{C}\right)$ for 3 weeks. The formulation subjected for stability study was stored in borosilicate container to avoid any interaction between the formulation and glass of container. The formulations were analyzed for any physical changes and drug content

\section{RESULT AND DISCUSSION}

\section{Preformulation}

\section{Characterization of Drug:}

Physiochemical Properties of Sulfasalazine

\section{A) Organoleptic evaluation}

It was found that Sulfasalazine is Light yellow Powder, Odorless and Tasteless fine powder.

\section{Table 6: Organoleptic property of} Sulfasalazine

\begin{tabular}{|l|l|}
\hline Drug & Sulfasalazine \\
\hline Color & Light yellow Powder \\
\hline Odor & Odorless \\
\hline Taste & Tasteless \\
\hline
\end{tabular}

\section{B) Solubility (at room temperature)}

It was found that Sulfasalazine was practically insoluble in water, freely soluble in ethanol and methanol.

Table 7: Solubility studies of Sulfasalazine in different solvent

\begin{tabular}{|l|l|l|}
\hline S. No. & Solvent Used & Sulfasalazine \\
\hline 1. & Water & Insoluble \\
\hline 2. & $0.1 \mathrm{~N} \mathrm{HCL}$ & Insoluble \\
\hline 3. & Ethanol & Soluble \\
\hline 4. & Methanol & Soluble \\
\hline 5. & Chloroform & Insoluble \\
\hline 6. & $0.1 \mathrm{~N} \mathrm{NaOH}$ & Soluble \\
\hline 7. & $\begin{array}{l}7.2 \mathrm{pH} \mathrm{Phosphate} \\
\text { Buffer }\end{array}$ & Soluble \\
\hline
\end{tabular}

\section{C) Identification Test}

\section{FTIR Spectroscopy:}

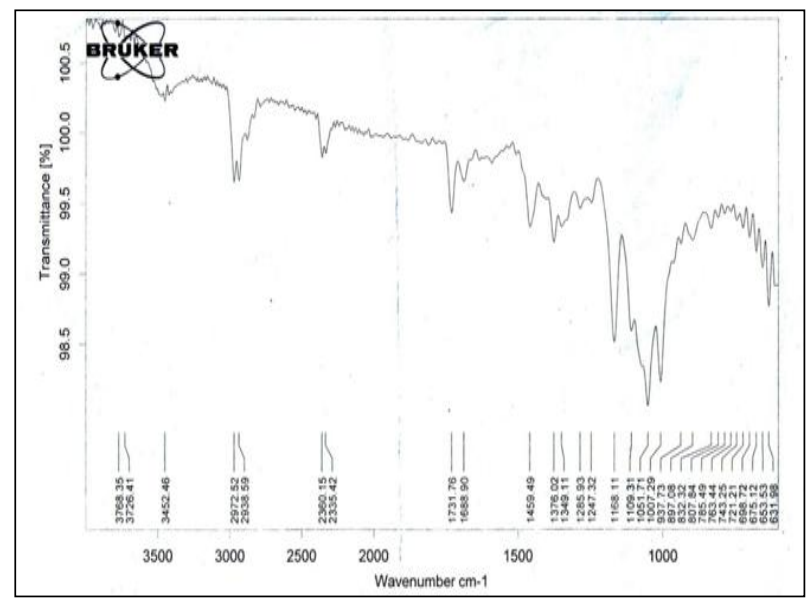

Figure 2: FT-IR Spectrum of Pure Drug (Sulfasalazine) 
Rakesh Tiwari et al., Journal of Biomedical and Pharmaceutical Research

\section{D) Loss on drying}

The percentage of loss on drying of Sulfasalazine was found to be $0.58 \% \mathrm{w} / \mathrm{w}$ respectively.

E) Determination of $\mathrm{pH}(1 \% \mathrm{w} / \mathrm{v}$ solution in water)

The $\mathrm{pH}$ of Sulfasalazine were determined by Digital $\mathrm{pH}$ meter and found to be 4.6.

\section{F) Melting point}

Melting point was determined by Melting

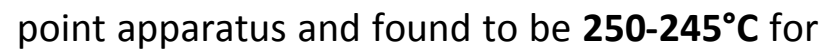
Sulfasalazine.

\section{M) Determination of $\lambda$ max of Sulfasalazine}

The absorption maxima of Sulfasalazine were determined by running the spectrum of drug solution in double beam ultraviolet spectrophotometer.

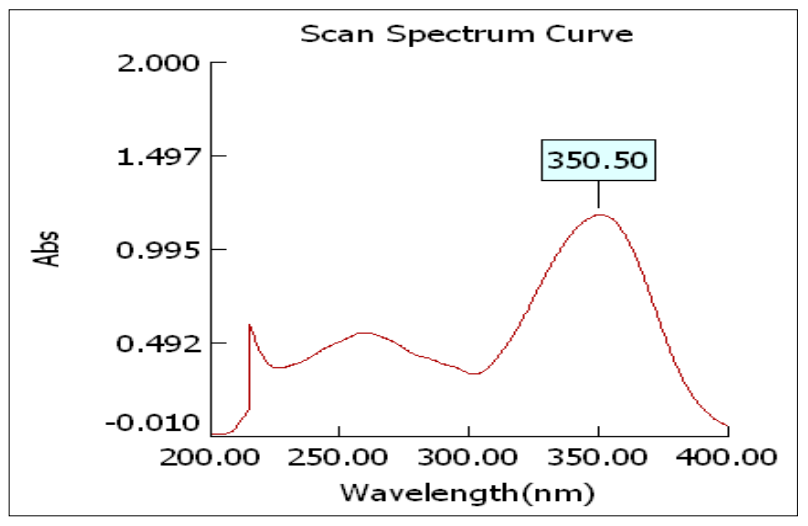

Figure 3: Determination of $\lambda$ max of Sulfasalazine

\subsection{Calibration curve of Sulfasalazine}

Table 8: Readings for Calibration curve of Sulfasalazine

\begin{tabular}{|c|c|c|c|c|c|}
\hline Replicate & $\mathbf{0}$ & $\mathbf{1 0}$ & $\mathbf{1 5}$ & $\mathbf{2 0}$ & $\mathbf{2 5}$ \\
\hline $\mathbf{1}$ & 0.111 & 0.206 & 0.316 & 0.425 & 0.535 \\
\hline $\mathbf{2}$ & 0.112 & 0.205 & 0.315 & 0.424 & 0.535 \\
\hline $\mathbf{3}$ & 0.111 & 0.204 & 0.314 & 0.423 & 0.534 \\
\hline Mean & 0.111 & 0.205 & 0.315 & 0.424 & 0.535 \\
\hline S.D. & 0.001 & 0.001 & 0.001 & 0.001 & 0.001 \\
\hline \% RSD & 0.519 & 0.488 & 0.317 & 0.236 & 0.108 \\
\hline
\end{tabular}

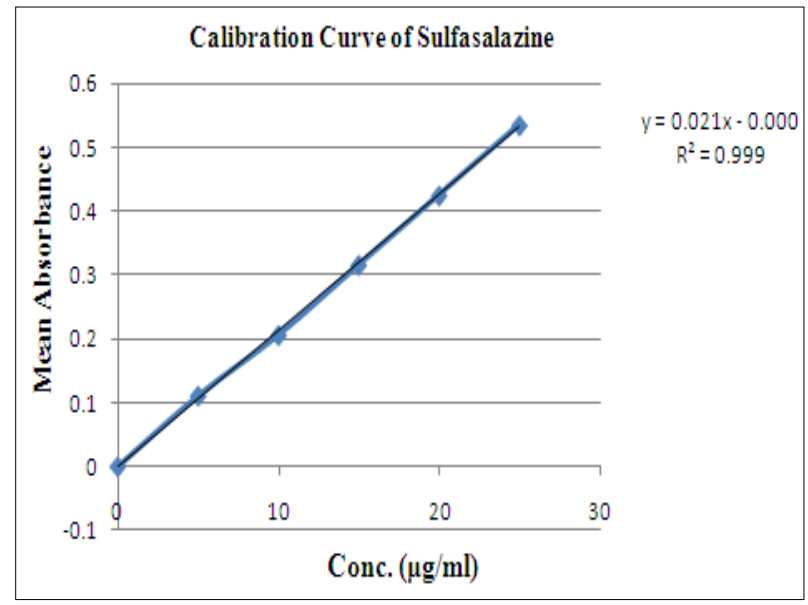

Figure 4: Calibration Curve of Sulfasalazine

Table 9: Stastical Data For Linearty

\begin{tabular}{|l|l|l|}
\hline S.No. & Parameter & Sulfasalazine \\
\hline 1 & Linearty Range & $5-25 \mu \mathrm{g} / \mathrm{ml}$ \\
\hline 2 & $\begin{array}{l}\text { Regression } \\
\text { Equation }\end{array}$ & $\begin{array}{l}\mathrm{Y}= \\
0.021 \mathrm{x}+0.000\end{array}$ \\
\hline 3 & $\begin{array}{l}\text { Correlation } \\
\text { Cofficient }\end{array}$ & 0.999 \\
\hline
\end{tabular}

Average Vesicle Size and Zeta Potential

Prepared formulations of liposomes were optimized on basis of vesicle size, shape, surface charge and entrapment efficiency. Vesicle size of liposomes were examined under trinocular microscopic (magnification 400X) and also determined by light scattering method (Malvern Zetasizer, ZEM 5002, and UK) and found that average vesicle size of optimized formulation F-9 was $178.37 \pm 5.07$ $\mathrm{nm}$. Zeta potential was $-36.20 \pm 3.2$. It was observed that the vesicles size of liposomes was increase with increasing the concentration of phosphotidylcoline and similarly vesicle size was decease with increasing the concentration of span 80 due to its surfactant action. There was no significant difference in average vesicle size was observed with increasing the drug concentration. But in increasing the sonication time the size vesicle was decrease from $218.42 \pm 6.09$ to $145.29 \pm 7.80$ after $90 \mathrm{sec}$ of sonication. 


\section{\% Entrapment efficiency}

\% Entrapment efficiency of optimized liposomes formulation (F-9) was found $71.03 \pm 2.49 \%$. It was observed that the percent drug entrapment was decrease with increasing the concentration of surfactant and on increasing the time of sonication. It is due to the leaching out the drug from vesicles on increasing the mechanical force by sonication and size reduction of size liposomes on increasing the concentration of surfactant due to their surfactant action. It was clearly shown in figure that when formulation was sonicate for $30 \mathrm{sec}$ then the \% EE was 72.03 \pm 2.39 (F-8) and when it sonicate for 60 and $90 \mathrm{sec}$ then the \%EE was found $71.03 \pm 2.49$ (F-9) and $45.48 \pm 3.23$ (F-10) respectively. The $60 \mathrm{sec}$ is selected as optimized time for sonication because it provided the required size of vesicle $178.37 \pm 5.07 \mathrm{~nm}$ and good \%EE i.e 71.03 \pm 2.49 . The F-9 formulation was selected as optimized formulation.

Table 10: Characterization of Optimized formulation of liposomes

\begin{tabular}{|l|l|l|l|}
\hline Characterization & $\begin{array}{l}\text { Average } \\
\text { vesicle } \\
\text { size }(\mathbf{n m})\end{array}$ & $\begin{array}{l}\text { \% Entrapment } \\
\text { efficiency }\end{array}$ & $\begin{array}{l}\text { Zeta } \\
\text { Potential } \\
\text { (mV) }\end{array}$ \\
\hline F-9 & $\begin{array}{l}178.37 \pm 5 . \\
07\end{array}$ & $71.03 \pm 2.49$ & $-36.20 \pm 3.2$ \\
\hline
\end{tabular}

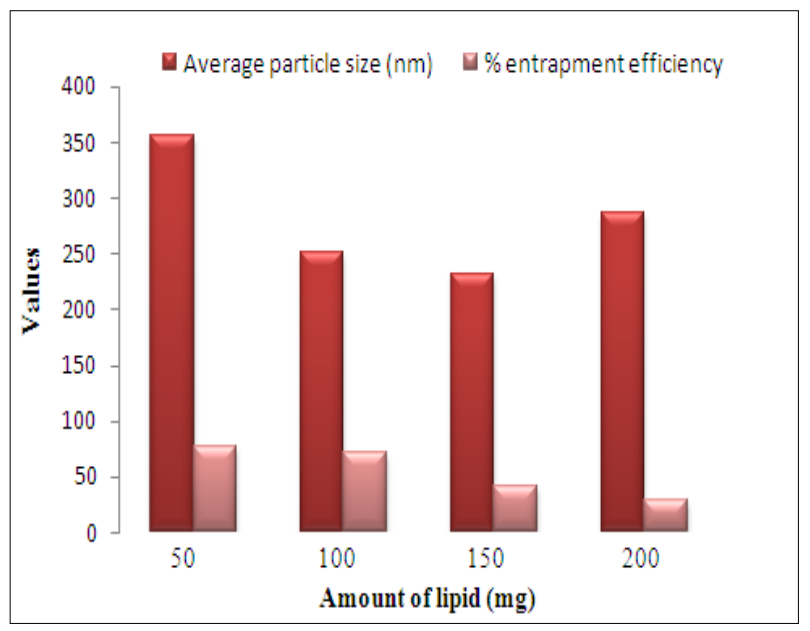

Figure 5: Effect of different ratio and concentration of soya PC on Vesicle size and Entrapment efficiency

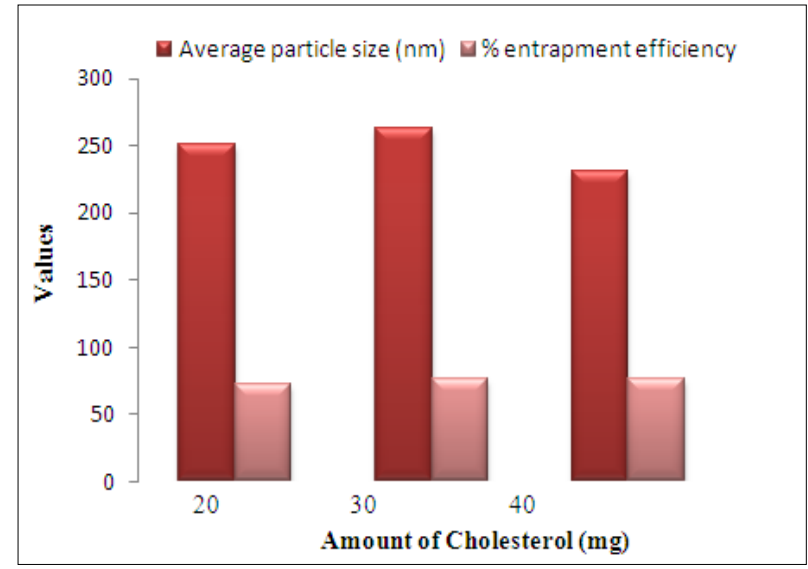

Figure 6: Effect of cholesterol concentration on vesicle size and Entrapment efficiency

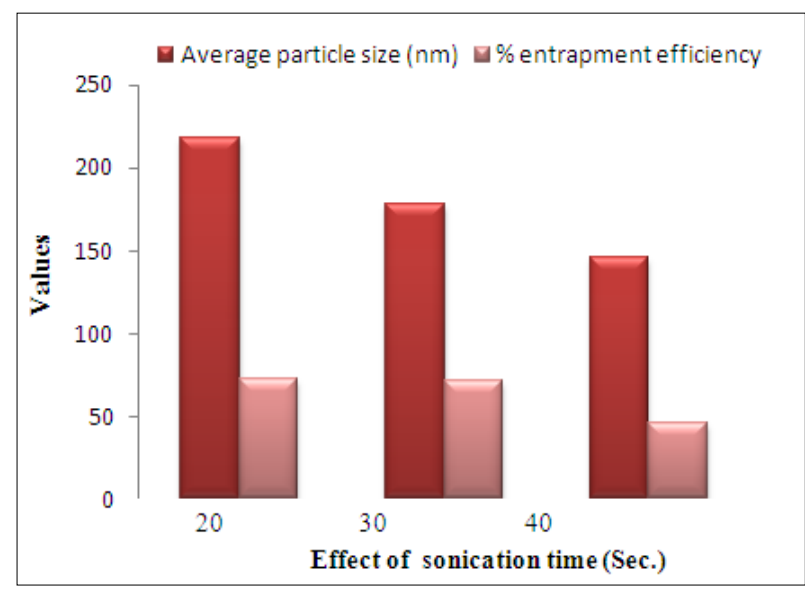

Figure 7: Effect of sonication time on vesicle size and Entrapment efficiency

Characterization of gel based formulation of prepared gel containing drug loaded Liposomes

Prepared gel was prepared and evaluate for viscosity, \% entrapment, extrudability, spreadability and drug release study. It was found that viscosity of prepared gel was $178.37 \pm 5.07 \mathrm{cps}, \%$ Entrapment efficiency was $71.03 \pm 2.49 \%$, Extrudability was170 $\mathrm{g}$ and Spreadibility (g.cm/sec) was found that 5.16 (g.cm/sec) respectively (table 8.3). In vitro drug release from liposomes was carried out using Frenze diffusion cell method and found $96.65 \pm 3.2 \%$ in $12 \mathrm{hr}$. It was due to the release of free drug present in bag after leaching from liposomes. Drug release from liposomes formulation was found in very sustained and controlled manner. 
Rakesh Tiwari et al., Journal of Biomedical and Pharmaceutical Research

Table 11: In vitro drug release study of prepared gel formulation

\begin{tabular}{|c|c|c|}
\hline S. No. & Time (hr) & \% Cumulative Drug Release \\
\hline 1 & 0.5 & $26.65 \pm 0.56$ \\
\hline 2 & 1 & $38.98 \pm 0.25$ \\
\hline 3 & 2 & $45.56 \pm 0.32$ \\
\hline 4 & 4 & $53.12 \pm 0.25$ \\
\hline 5 & 6 & $69.98 \pm 0.14$ \\
\hline 6 & 8 & $89.98 \pm 0.25$ \\
\hline 7 & 10 & $95.56 \pm 0.65$ \\
\hline 8 & 12 & $98.98 \pm 0.32$ \\
\hline
\end{tabular}

*Average of three determination

Table 12: Characterization of gel based formulation of liposomes

\begin{tabular}{|l|l|l|l|l|l|}
\hline Characterization & Viscosity (cps) & \% Assay & $\begin{array}{l}\text { Release } \\
\text { after } \mathbf{1 2 h r}\end{array}$ & $\begin{array}{l}\text { Extrudability } \\
\text { (g) }\end{array}$ & $\begin{array}{l}\text { Spreadibility } \\
\text { (g.cm/sec) }\end{array}$ \\
\hline LG-1 & $178.37 \pm 5.07$ & $99.45 \pm 0.45$ & $98.98 \pm 0.32$ & $170 \pm 8$ & $5.16 \pm 1.05$ \\
\hline
\end{tabular}

LG- Liposomal gel formulation

\section{Stability Study}

Stability study data was revealed that the optimized formulation (F-9) stable after 3 month of storgae at $4 . \mathrm{C} \mathrm{C}$ while at $25-28 \pm 2^{\circ} \mathrm{C}$, the formulation was found unstable. Stability of formulation was observed on the basis of $\%$ drug remain, average vesicles size and physical appearance. The average vesicle size of liposomes was found $178.37 \pm 5.07$, $179.32 \pm 2.49$ and $186.84 \pm 5.84 \mathrm{~nm}$ after 1,2 and 3 month of storage at $4.0 \pm 0.2^{\circ} \mathrm{C}$ while at
$25-28 \pm 2^{\circ} \mathrm{C}$ the average vesicle size was found $192.56 \pm 3.43,238.54 \pm 4.87$ and $583.54 \pm 6.99 \mathrm{~nm}$ after 1, 2 and 3 month of storage. Drug remaining in liposomal formulation was $48.62 \pm 1.39, \quad 35.29 \pm 1.08$ and $23.83 \pm 2.11 \%$ after 1,2 and 3 month of storage at $25-28 \pm 2^{\circ} \mathrm{C}$ while there was no significant changes in \% drug remain and physical appearance in liposomal formulation was observed after 3 month of storage at $4 \stackrel{\circ}{ } \mathrm{C}$.

Table 13: Characterization of Optimized formulation of liposomes

\begin{tabular}{|c|c|c|c|c|c|c|}
\hline \multirow{3}{*}{$\begin{array}{l}\text { Characteristic } \\
\text { Temperature }\end{array}$} & \multicolumn{6}{|c|}{ Time (Month) } \\
\hline & \multicolumn{2}{|c|}{1 Month } & \multicolumn{2}{|c|}{2 Month } & \multicolumn{2}{|c|}{3 Month } \\
\hline & $4.0 \pm 0.2^{\circ} \mathrm{C}$ & $25-28 \pm 2^{\circ} \mathrm{C}$ & $4.0 \pm 0.2^{\circ} \mathrm{C}$ & $25-28 \pm 2^{\circ} \mathrm{C}$ & $4.0 \pm 0.2^{\circ} \mathrm{C}$ & $25-28 \pm 2^{\circ} \mathrm{C}$ \\
\hline $\begin{array}{c}\text { Average particle } \\
\text { size }(\mathrm{nm})\end{array}$ & $178.37 \pm 5.07$ & $192.56 \pm 3.43$ & $179.32 \pm 2.49$ & $238.54 \pm 4.87$ & $186.84 \pm 5.84$ & $583.54 \pm 6.99$ \\
\hline$\% \mathrm{EE}$ & $67.37 \pm 2.52$ & $48.62 \pm 1.39$ & $62.37 \pm 2.52$ & $35.29 \pm 1.08$ & $52.37 \pm 2.52$ & $23.83 \pm 2.11$ \\
\hline $\begin{array}{c}\text { Physical } \\
\text { Appearance }\end{array}$ & Normal & High turbid & Normal & $\begin{array}{l}\text { High turbid and } \\
\text { agglomeration }\end{array}$ & Normal & $\begin{array}{l}\text { High turbid and } \\
\text { agglomeration }\end{array}$ \\
\hline
\end{tabular}




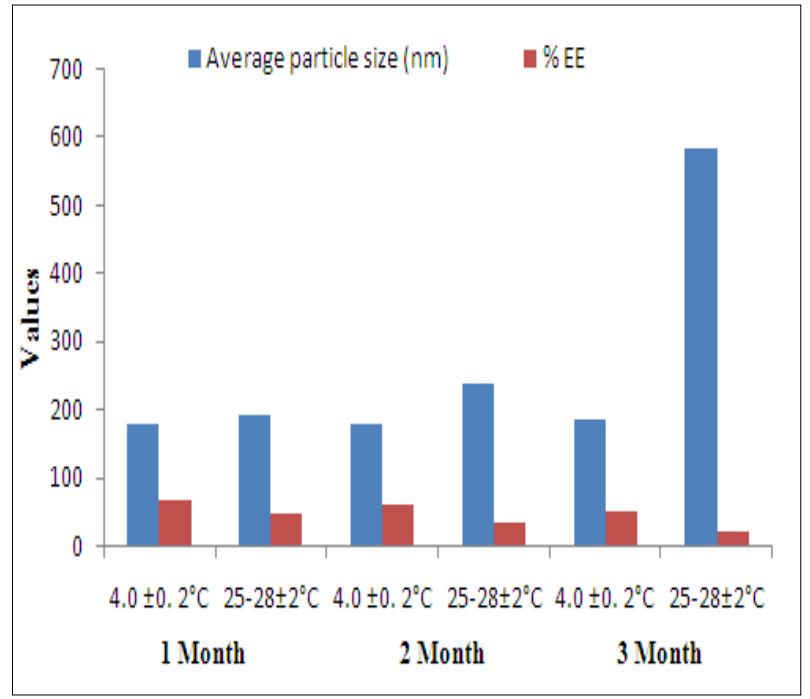

Figure 8: Average vesicle size of after storage at different temperature for $\mathbf{3}$ month.

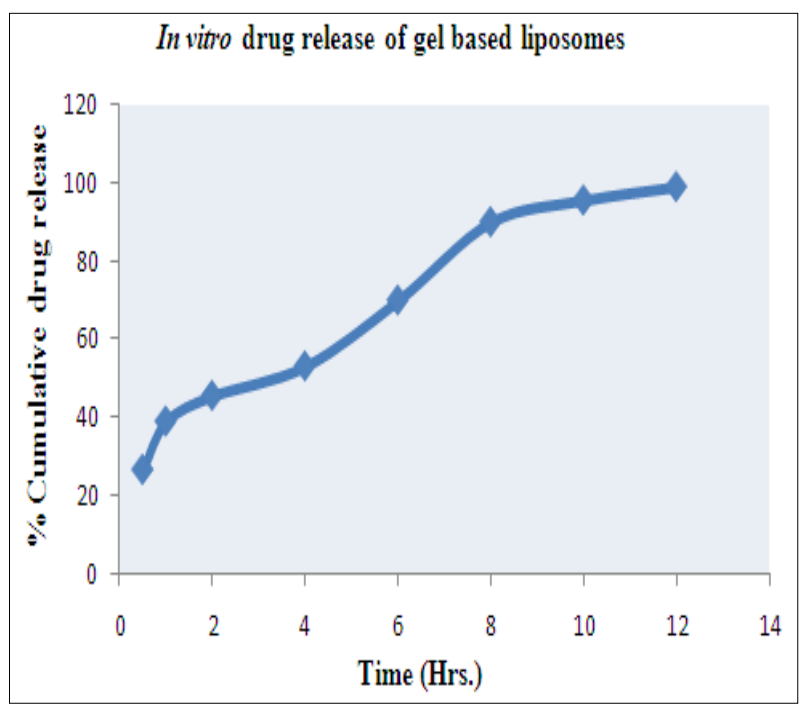

Figure 9: In vitro drug release of gel based liposomes

\section{CONCLUSION}

Liposomes were prepared by rotator evaporation method and optimized on the basis of average vesicle size, \% drug entrapment and polydispersity index. The optimized formulation was further encorpoated with gel base (carbapol gel) and characterized for their viscosity, extrudability, spreadability and drug release study. Liposomes were found $178.37 \pm 5.07 \mathrm{~nm}$ in average vesicle size, $71.03 \pm 2.49 \%$ entrapment efficiency, and $-36.20 \pm 3.2 \mathrm{mv}$ of zeta potential. Prepared gel was prepared and evaluate for viscosity, \% entrapment, extrudability, spreadability and drug release study. It was found that viscosity of prepared gel was $178.37 \pm 5.07 \mathrm{cps}, \%$ Entrapment efficiency was $71.03 \pm 2.49 \%$, Extrudability was170 $\mathrm{g}$ and Spreadibility (g.cm/sec) was found that 5.16 (g.cm/sec) respectively. In vitro Drug Release: In vitro drug release from liposomes was carried out using Frenze diffusion cell method. Drug release from liposomes formulation was found in very sustained and controlled manner. It was concluded that prepared gel containing Sulphasalazine loaded liposomal formulation was optimized and successfully formulated in the form gel can be use for topical preparation for treatment of rheumatoid arthritis.

\section{REFERENES}

1. Abolfazl A, Rogaie $R$, Soodabeh $D$, Sang WJ, Nosratollah $Z$, Younes $H$, et al. Liposome: classification, preparation and application. Nanoscale Res Lett 2013; 8:29.

2. Gregoriadis G. Liposome research in drug delivery and targeting. In: Dorulo D, Lasic, Papahadjopoulos D, editors. Medical application of liposomes. Amsterdam: Elsevier Sci; 1998. pp. 9-13.

3. Rossum V. Sulfasalazine in the Treatment of Juvenile Chronic Arthritis: A Randomized, Double-Blind, PlaceboControlled, Multicenter Study. Arth Rheum. 2004; 41:808-816.

4. Jaiswal P., Kesharwani S., Kesharwani R., Patel D. Ethosome: a new technology used as topical \& transdermal delivery system. Journal of Drug Delivery and Therapeutics, 2016; 6(3):7-17.

5. Carteersen JT, Preformulation. In: Banker GS, Rhodes CT. Modern Pharmaceutics. 8th ed. New York: Marcel Dekker; 2002. p. 167-186.

6. Chaurasia G.A Review on Pharmaceutical Preformulation Studies in Formulation and Development of New Drug Molecules. International Journal of 
Rakesh Tiwari et al., Journal of Biomedical and Pharmaceutical Research

Pharmaceutical Science and research, 2016, 7(6):2313-2320.

7. Neha VM, Namita Thakor M, Sini CS, Viral Shah $H$. Formulation optimization and evaluation of Liposomal gel of prednisolone by applying statistical design; Indian Journal of Research in Pharmacy and Biotechnology 2013; 1(2):180-187.

8. Jain $\mathrm{S}$, Jain $\mathrm{N}$, Bhadra $\mathrm{D}$, Tiwary AK, Jain NK. Transdermal delivery of an analgesic agent using Elastic liposomes: Preparation, characterization and performance evaluation. Curr Drug Deliv. 2005b; 2(3):222-233.

9. Yasmin Begum M, Abbulu K, Sudhakar M. Design and evaluation of flurbiprofen liposomes. J Pharm Res 2011; 4:653-5.

10. Srinivas MBR, Vishakha K, Prakash $P$, Jamal BD, Govardhan T, Muni SP. Formulation and in vitro evaluation of liposomes loaded with mupirocin. Int J Res Pharm Nano Sci 2015; 4:162-74.
11. Devi $R$, Prasad CM, Renganathan $A$, Kasthuri S, Sundharanjan R, Deepa N. Formulation, characterization and evaluation of fluconazole liposomes. Pharm Sin 2015; 6:61-6.

12. Gupta V, Barupal AK, Ramteke S. Formulation, development and in vitro characterization of liposomes for topical delivery of acelofenac. Indian Journal of Pharmaceutical Sciences 2010; 70(6):768775.

13. Abdel-Mottaleb MMA, Mortada ND, Elshamy AA, Awad GAS. Preparatio and evaluation of fluconazole gels. Egypt. J. Biomed. Sci. 2007; 23:266-286.

14. Mohamed MN. In vitro release of hydrophilic and hydrophobic drugs from liposomal dispersions and gels. Act. Pharm. 2006; 56:311-324.

15. Glavas-Dodov M. Formulation and characterization of topical liposome gel bearing lidocaine $\mathrm{HCl}$. Bull. Chem. Tech. Macedonia. 2005; 24(1):59-65. 